\title{
The Surgical Management of Acute Esophageal Perforation by Accidentally Ingested Fish Bone
}

\author{
Elena Adelina Toma1, Mohammad Oun', Octavian Enciü ${ }^{1,2}$, Valentin Calu ${ }^{1,2}$, Adrian Miron ${ }^{1,2}$ \\ 'Elias University Emergency Hospital - Surgery Department, Bucharest, Romania

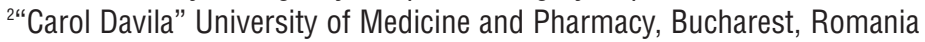

Corresponding author: Valentin Calu, MD, PhD Elias University Emergency Hospital Bucharest, Romania

E-mail: drcalu@yahoo.com

\section{Rezumat}

Managementul chirurgical al perforatiei acute de esofag prin ingestie accidentală a unui os de pește

Corpii strãini esofagieni sunt o patologie relativ frecventã, care nu necesitã tratament în pânã la $80 \%$ din cazuri. Între 10-20\% dintre pacienți sunt tratați endoscopic, în timp ce mai puțin de $1 \%$ din cazuri necesitã intervenție chirurgicalã, fie din cauza unei perforații, fie pentru a trata complicații. Prezentãm cazul unui pacient în vârstã de 50 de ani care s-a prezentat la spital cu un corp strãin esofagian impactat, care perforase peretele. S-a intervenit endoscopic şi s-a confirmat diagnosticul, identificându-se şi corpul strãin ca fiind un os de peste de mari dimensiuni pozitionat transversal la nivelul esofagului cervical distal, care nu a putut fi mobilizat utilizând endoscopul flexibil. S-a intervenit chirurgical de urgențã şi s-a practicat extragerea corpului strãin cu sutura peretelui esofagian în dublu strat, ceea ce nu a prevenit însã apariția unei fistule esofagiene în ziua 17 postoperator, complicație tratatã conservator. Deşi este rareori întâlnitã în tratamentul corpilor strãini de la nivel gastro-intestinal, intervenția chirurgicalã este obligatorie în cazurile în care extragerea endoscopicã nu se poate realiza, precum şi dacã sunt identificate perforații la nivelul peretelui esofagian.

Cuvinte cheie: corp strãin esofagian, os de peste impactat, perforație esofagianã

\section{Abstract}

Esophageal foreign bodies are a relatively frequent pathology which 
does not need any kind of treatment in up to $80 \%$ of cases. Ten to $20 \%$ of patients are treated endoscopically, while less than $1 \%$ need surgery either due to perforation or to treat complications. We address the case of a 50 year old male who presented with an impacted esophageal foreign body which had perforated the esophageal wall. Flexible endoscopy confirmed the diagnosis and identified a large fish bone that was stuck transversally in the distal cervical esophagus and could not be mobilized. Surgery was mandatory in this case, with the extraction of the bone and double-layer suture, which did not prevent the appearence of an esophageal leakage more than two weeks postoperatively, which was treated conservatively. Even if it is rarely employed in the treatment of gastrointestinal foreign bodies, surgical treatment is unavoidable in cases of irretrievable esophageal foreign bodies or esophageal perforation.

Key words: esophageal foreign body, impacted fish bone, perforatie esofagiana

\section{Introduction}

Foreign bodies in the upper gastrointestinal tract are somewhat frequent in children, but they are also reported in adults, usually occurring in either in elderly patients, or in cases which associate intellectual impairment, alcohol abuse or psychiatric conditions (1). In adults, esophageal food bolus impaction is a pathology with an estimated annual incidence of $13 / 100000$ people (2). Most foreign body ingestions in adults are related to eating, leading to either bone or meat bolus impaction (3). While most cases don't require any kind of treatment, only $20 \%$ have endoscopic procedures performed and less than 1\% undergo surgery $(1,4)$.

We report a rare case of a fish bone impacted transversally in the esophagus, with perforation of the left lateral wall and associated abscess, which could not be treated endoscopically and required emergency surgery.

\section{Case Report}

A 50-year old male was brought to the emergency room complaining of dyspnea. $\mathrm{He}$ mentioned consumption of sea food one day before and was doubtful about having swallowed a fish bone. The patient was unsure about the exact period of time elapsed from the event, situating it between 20 to 24 hours prior to admission.
His vital signs were stable $(\mathrm{BP}=140 / 70$ $\mathrm{mmHg}, \mathrm{HR}=82 \mathrm{bpm}, \mathrm{SpO} 2=95 \%, \mathrm{~T}=36.7^{\circ} \mathrm{C}$ ) with a Glasgow Coma Scale score of 15 , without any known co-morbidities. He was a smoker and frequent alcohol consumer.

During physical examination, subcutaneous cervical and thoracic emphysema were found. The rest of the examination was normal. Blood exams revealed leucocytosis $(\mathrm{WBC}=22.300$ $\left./ \mathrm{mm}^{3}\right)$, blood glucose $=160 \mathrm{mg} / \mathrm{dl}$, creatinin $=$ $1.3 \mathrm{mg} / \mathrm{dl}$, urea $=63 \mathrm{mg} / \mathrm{dl}$.

Neck and chest films confirmed the subcutaneous latero-cervical emphysema which extended bilaterally, but no foreign bodies could be identified. After admission into the surgical ward, an emergency CT scan was performed that demonstrated a large foreign body presumably a fish bone - horizontally impacted in the esophageal wall, distally, at about $2.5 \mathrm{~cm}$ below the cricoid cartilage, anteriorly to the C7-T1 intervertebral space (Fig.1). It also diagnosed pneumomediastinum, right small pneumothorax and a large subcutaneous emphysema in the entire cervical region, in the supraclavicular fossa - bilaterally and to a lesser extent in the superior part of the thorax.

An esophageal endoscopy using a flexible endoscope confirmed the presence of the foreign body $14 \mathrm{~cm}$ below the dental arcade, embedded in an impacted food bolus, with what seemed like a bone positioned transversally in the esophageal lumen, which could not be mobilized. Proximally to this bolus an 


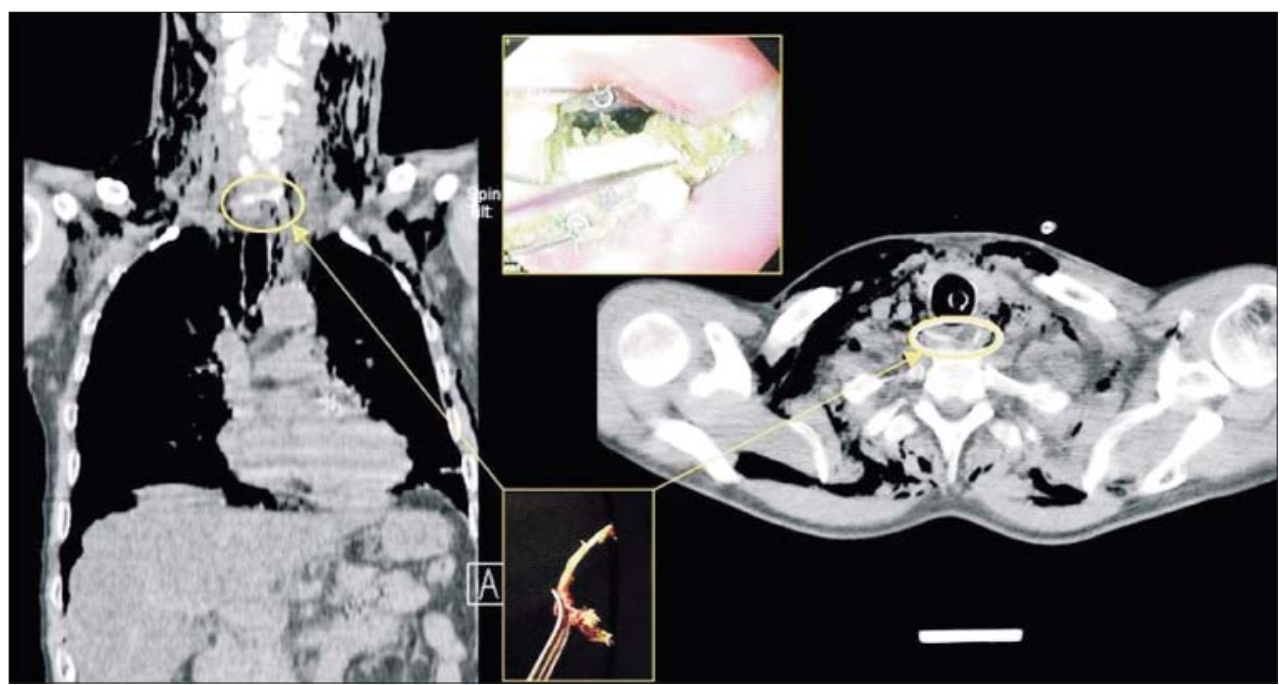

Figure 1. CT and Upper Endoscopy findigs

esophageal ulceration of approximately $2 \mathrm{~cm}$ diameter was also visualized. Due to its size, position and transfixion, removal of the bone was deemed inappropriate and unsafe; any attempt to extract the foreign body was unsuccessful with an increase of the subcutaneous emphysema.

The patient was taken to the OR and the ENT team also tried to remove the bone using a long laryngoscope after the patient was intubated, but the foreign body was inaccessible.

After a brief case discussion between the general surgeon, the thoracic surgeon, the ENT doctors and anesthesiologists, emergency surgery was reckoned necessary. A left oblique cervical incision was performed and after careful dissection, a small cervical abscess was observed (Fig. 2), which was consequently drained, with the pus was sampled for bacteriology exam, which later showed the presence of Streptococcus pneumoniae, with antibiotic sensibility to all the panel. The cervical esophagus was identified and dissected, the esophageal wall had been perforated and the impacted foreign body, measuring almost $3 \mathrm{~cm}$ in length, was extracted followed by doublelayer esophageal suture, covered by a muscular flap from the sternocleidomastoidian muscle. (Figs. 3, 4). After cleaning the operative field with betadine solution, two drains were inserted, one near the suture line and one in the mediastinum. A nasogastric tube was also inserted in order to feed the patient postoperatively.

The patient remained fasting and received parenteral nutrition, with a 7-day course of combined antibiotic therapy (cefuroxime, metronidazole and gentamicin), with a good

Figure 2. Periesophageal cervical abscess

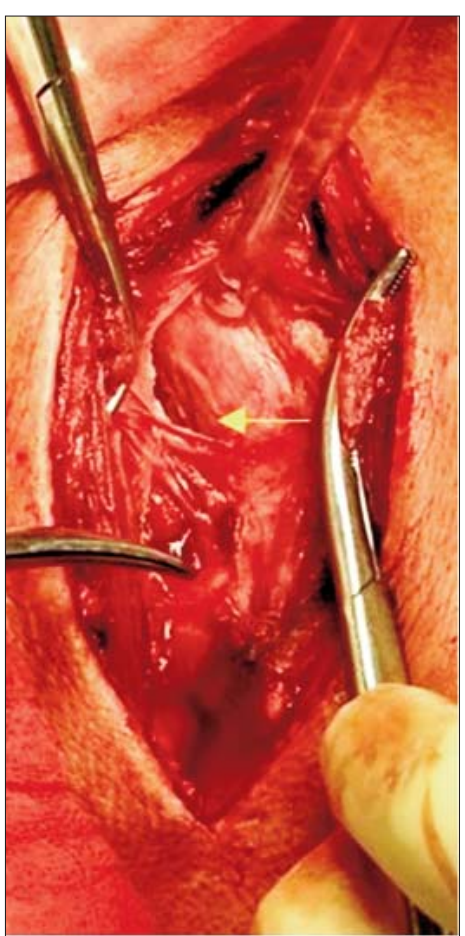




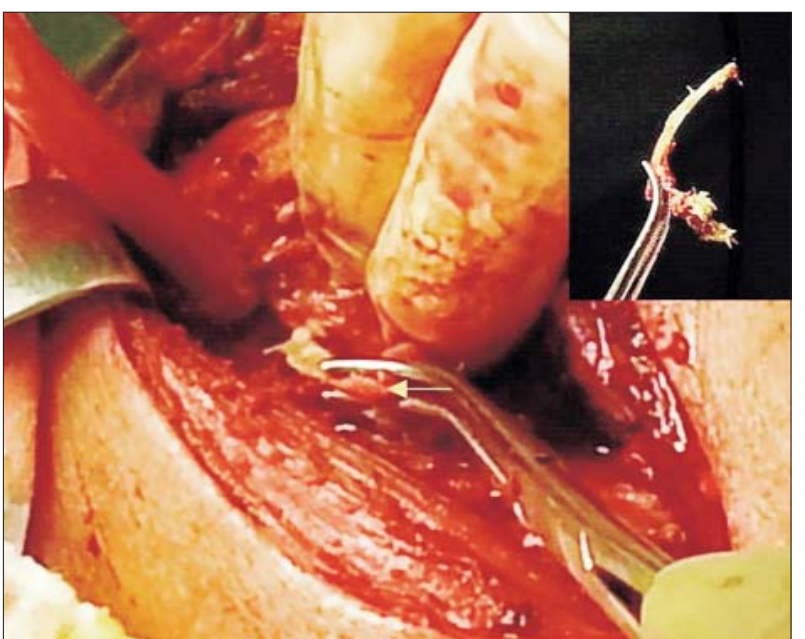

Figure 3. Esophageal perforation and the foreign body (fish bone)

initial postoperative outcome, no signs of sepsis, and the normalization of the WBC count.

A first radiologic evaluation was performed three days after the surgery, which showed remission of the emphysema. One week postoperatively, before starting the oral feeding, the patient underwent an esophagram with liquid barium which showed no postoperative complications and the drain placed near the suture line was removed (Fig. 5A). Considering the fact that the esophageal suture was performed after 20 hours from the perforation, we decided to postpone the resuming of the oral feeding. The patient received parenteral nutrition combined with enteral nutrition via the nasogastric tube and was instructed not to swallow the saliva. No leakage on the cervical drain was observed. Another barium swallow was done during postoperative day 17 , which in turn revealed an esophageal leakage in the left lateral wall of the inferior esophagus, as well as a pseudodiverticulum of approximately $35 / 27 \mathrm{~mm}$, which were managed conservatively,

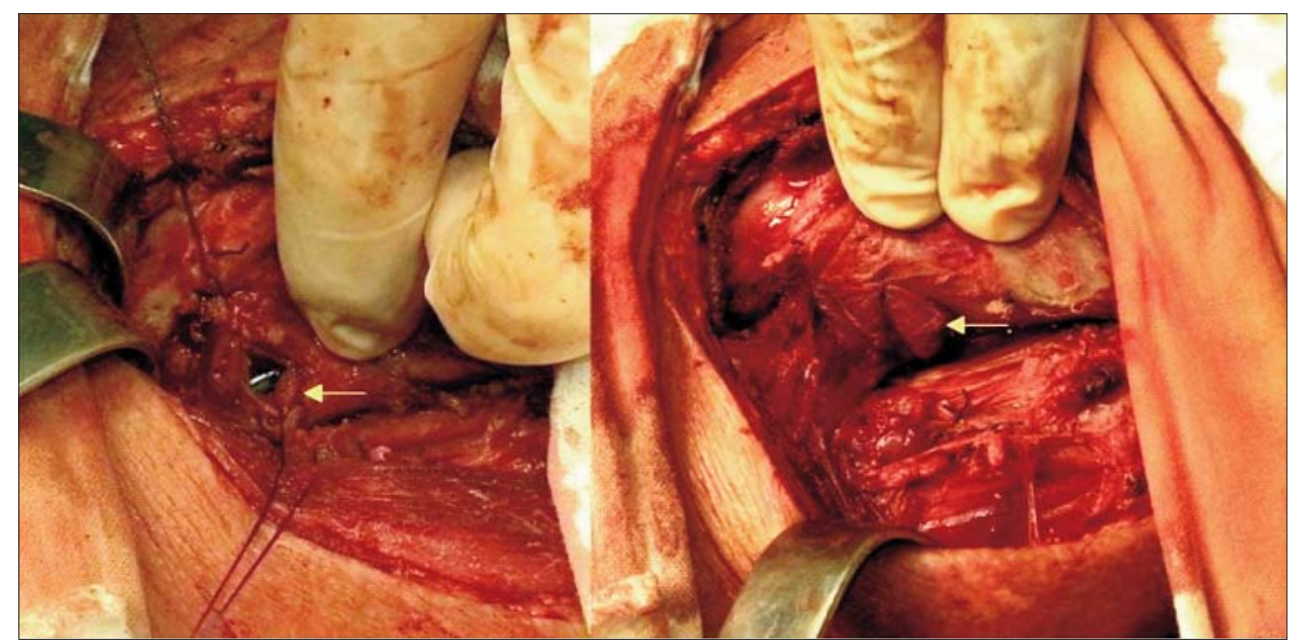

Figure 4. Esophageal perforation - repair

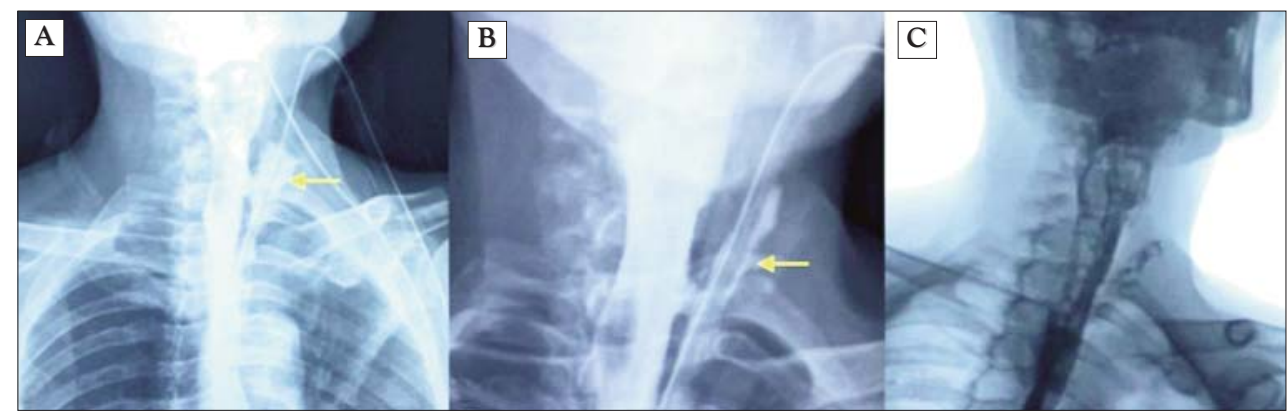

Figure 5. Barium swallow: A - postoperative day $7, \mathrm{~B}$ - postoperative day $17, \mathrm{C}$ - postoperative day 29 
as the patient was kept on enteral and parenteral nutrition (Fig. 5B). The amount of drainage was below $50 \mathrm{ml}$, with Pseudomonas aeruginosa isolated from the fluid, sensible only to Colistin, which was administered for 11 days. The fistula was monitored using weekly esophagram. The patient's course was gradually for the better, with complete remission of the subcutaneous emphysema, proper healing of the postoperative wound with no signs of surgical site infection, and normal blood tests. The second drain was removed during postoperative day 29 (Fig. 5C).

Forty-two days after surgery the patient began oral nutrition with very good tolerance and no signs of any complications.

A final esophagram was performed on postoperative day 44 which showed no signs of leakage and the patient was discharged (Fig. 6) in good condition and is scheduled to come back for reevaluation after a month.

\section{Discussion}

The ingestion of gastrointestinal foreign bodies is a fairly common occurrence which prompts emergency diagnosis and adequate treatment, but a consensus has not yet been reached regarding their removal or the imaging technique that should be used for diagnosis. This is mainly due to a limited number of studies and guidelines, as this pathology rarely presented complications such as perforation or obstruction and their management was even more scarcely of surgical nature. A significant number of these cases occur in children, while adults who ingest foreign objects are most commonly impaired by other afflictions such as psychiatric conditions, intellectual disability or alcoholism $(1,6-11)$. The patient we presented falls into this reported pattern, being a known alcoholic and with a poor social status.

While most ingested foreign bodies, if they reach the gastroesophageal junction, pass through without complication (up to $90 \%$ of cases), approximately $10-20 \%$ need to be removed endoscopically and less than 1\% perforate, while reports indicate that $1-14 \%$ of cases require a surgical approach either for

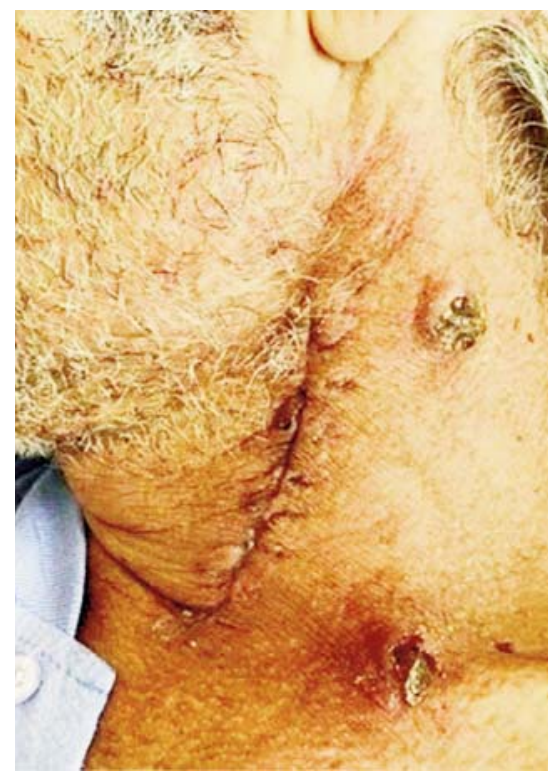

Fig.6 Wound aspect at discharge

removal of the impacted body, or to treat complications (4-8). In our case, the surgical procedure was planned after the CT scan confirmed esophageal perforation and the endoscopic procedure was performed mainly to complete the diagnostic algorithm. The transversal impactation of the foreign body already made any attempt of endoscopic removal of the fish bone pointless and extremely dangerous. Sharp objects, especially those stuck in the esophagus (one third of cases), remain the main concern and have been the subject of debate between medical specialties, seen as the methods of diagnosis and subsequent management vary highly, as does the rate of complications following sharp object ingestion (4$7,12,13)$. Fish bones are a common finding in such cases (up to $31 \%$ ), but their impaction in the esophageal wall make it more difficult to detect using physical examination and plain cervical radiographic films, which can lead to delayed treatment and more frequent complications such as retroesophageal abscess, mediastinits, empyema or even aortoesophageal fistula $(5-7,12,14)$. The choice of treatment depends on numerous variables, such as the size, shape and exact location of the bone, as well as airway control, the skills of the physician and the available options, but 
endoscopy is the current first choice in such cases, be it rigid or flexible, but other therapeutic methods include dislodgement by a Foley catheter, advancement with a bougie or carbonated fluid treatment $(1,4,6-9,14)$.

Surgery is considered unavoidable when complications are present at admission, visible on $\mathrm{CT}$ or the previous methods of treatment fail and the surgical approach also depends on the size, shape and location of the body, as well as the surgeon's experience and comfort $(1,6,7,15-17)$. Our case had a strong surgical indication, since the endoscopic attempt to extract the bone was unsuccessful. The surgical attitude can vary depending on the time elapsed from the perforation, the position and location of the foreign body, the quality of the esophageal wall, as well as the condition of the patient and the presence of sepsis with hemodynamic instability. Since our patient was stable, with a mild cervical infection, we decided to perform the suture of the perforation. Because the bone was located in the cervical segment of the esophagus and visible, no intraoperative endoscopy was considered necessary.

The initial antibiotherapy should cover a wide spectrum, as we did in our case, since only common microbes are identified. If a leakage occurs, repeated cultures should be performed, and empiric antibiotherapy is replaced with targeted antibiotics.

The main problem remains the nutrition, oral feeding should not be resumed before performing the esophagram. Cervical esophageal fistulas are usually easy to manage, the nutrition has to be ensured via parenteral way. Sometimes a jejunostomy or a percutaneous endoscopic gastrostomy have to be perfomed, if the oral feeding is not possible for longer periods of time. In our case, we used parenteral nutrition initially, and later, when the leakage occurred, feeding through the nasogastric tube was associated with good results.

Mortality rates remain extremely low across multiple studies, with no deaths reported in adults who ingested foreign objects in two large series adding up to 2252 patients $(6,7)$.

\section{Conclusions}

Although rarely needed, the surgical management of esophageal foreign bodies can seldom be unavoidable. It is of the utmost importance that doctors recognize these cases and approach them accordingly, as emergency interventions might prove life-saving especially in instances such as this, which involve an atypical position of the impacted bone with complications present at admission and highly difficult endoscopic maneuvers.

\section{References}

1. Athanassiadi K, Gerazounis M, Metaxas E, Kalantzi N. Management of esophageal foreign bodies: a retrospective review of 400 cases. European journal of cardio-thoracic surgery. 2002;21(4):653-6.

2. Longstreth GF, Longstreth KJ, Yao JF. Esophageal food impaction: epidemiology and therapy. A retrospective, observational study. Gastrointestinal endoscopy. 2001;53(2):193-8.

3. Roura J, Morelló A, Comas J, Ferrán F, Colomé M, Traserra J. Esophageal foreign bodies in adults. ORL. 1990;52(1):51-6.

4. Birk M, Bauerfeind P, Deprez PH, Häfner M, Hartmann D, Hassan C, et al. Removal of foreign bodies in the upper gastrointestinal tract in adults: European Society of Gastrointestinal Endoscopy (ESGE) Clinical Guideline. Endoscopy. 2016;48(5):489-96. doi: 10.1055/ s-0042-100456. Epub 2016 Feb 10.

5. Woo SH, Kim KH. Proposal for methods of diagnosis of fish bone foreign body in the esophagus. The Laryngoscope. 20151;125(11): 2472-5.

6. Li ZS, Sun ZX, Zou DW, Xu GM, Wu RP, Liao Z. Endoscopic management of foreign bodies in the upper-GI tract: experience with 1088 cases in China. Gastrointestinal endoscopy. 2006;64(4): 485-92.

7. Zamary KR, Davis JW, Ament EE, Dirks RC, Garry JE. This too shall pass: A study of ingested sharp foreign bodies. Journal of Trauma and Acute Care Surgery. 2017;82(1):150-5.

8. Ikenberry SO, Jue TL, Anderson MA, Appalaneni V et al. Management of ingested foreign bodies and food impactions. Gastrointestinal endoscopy. 2011;73(6):1085-91.

9. Eisen GM, Baron TH, Dominitz JA, Faigel DO, Goldstein JL, Johanson JF, Mallery JS, Raddawi HM, Vargo JJ, Waring JP, Fanelli RD. Guideline for the management of ingested foreign bodies. Gastrointestinal endoscopy. 2002;55(7):802-6.

10. Velitchkov NG, Grigorov GI, Losanoff JE, Kjossev KT. Ingested foreign bodies of the gastrointestinal tract: retrospective analysis of 542 cases. World J Surg. 1996;20(8):1001-5.

11. Webb WA. Management of foreign bodies of the upper gastrointestinal tract: update. Gastrointestinal endoscopy. 1995;41(1):39-51.

12. Weissberg D, Refaely Y. Foreign bodies in the esophagus. The Annals of thoracic surgery. 2007;84(6):1854-7.

13. Stack LB, Munter DW. Foreign bodies in the gastrointestinal tract. Emergency medicine clinics of North America. 1996;14(3):493-522.

14. Smith MT, Wong RK. Esophageal foreign bodies: types and techniques for removal. Current treatment options in gastroenterology. 2006; 9(1):75-84.

15. McCanse DE, Kurchin A, Hinshaw JR. Gastrointestinal foreign bodies. The American Journal of Surgery. 1981;142(3):335-7.

16. McCanse DE, Kurchin A, Hinshaw JR. Gastrointestinal foreign bodies. The American Journal of Surgery. 1981;142(3):335-7.

17. Watanabe K, Amano M, Nakanome A, Saito D, Hashimoto S. The prolonged presence of a fish bone in the neck. The Tohoku journal of experimental medicine. 2012;227(1):49-52. 